KINERJA Jurnal Ekonomi dan Bisnis

Vol. 4 No. 1 - Desember 2021

\title{
PENGARUH KOMPENSASI DAN KEPUASAN KERJA TERHADAP TURNOVER INTENTION PADA KARYAWAN OFFICE PT CIPTA NUGRAHA CONTRINDO
}

\author{
Meindro Waskito \\ Ayu Rachmawati Putri \\ Program Studi Manajemen Fakultas Ekonomi dan Bisnis \\ Universitas Islam As-Syafi'iyah
}

\begin{abstract}
Abstrak
Tujuan dalam penelitian untuk mengetahui pengaruh Kompensasi dan Kepuasan Kerja terhadap turnover intention karyawan office pada PT Cipta Nugraha Contrindo, dilakukan pada seluruh karyawan office, dengan sampel penelitian ini berjumlah 64 orang karyawan dengan menggunakan sample jenuh. Metode pengumpulan data dengan penyebaran kuisoner untuk memperoleh data primer dengan analisis data yang digunakan dengan analisis regresi sederhana dengan persamaan regresi, koefisien korelasi, koefisien determinasi dan uji hipotesis ( uji t ) dengan menggunakan program SPSS 26. Berdasarkan hasil analisis data dan pengujian hipotesis yang telah dilakukan menunjukkan bahwa secara parsial kompensasi $\left(\mathrm{X}_{1}\right)$ berpengaruh yang rendah, negatif dan signifikan terhadap turnover intention $(\mathrm{Y})$. Begitu juga kepuasan kerja $\left(\mathrm{X}_{2}\right)$ secara parsial menunjukkan bahwa terdapat pengaruh yang rendah, negatif dan signifikan terhadap turnover intention (Y) karyawan office PT Cipta Nugraha Contrindo.
\end{abstract}

Kata Kunci : Kompensasi, Kepuasan Kerja, Turnover Intention

\begin{abstract}
The purpose of this study was to determine the effect of compensation and job satisfaction on turnover intention of office employees at PT Cipta Nugraha Contrindo, carried out on all office employees, with a sample of 64 employees using a saturated sample. The method of data collection by distributing questionnaires to obtain primary data with data analysis used by simple regression analysis with regression equations, correlation coefficients, coefficients of determination and hypothesis testing ( $t$ test) using the SPSS 26 program. Based on the results of data analysis and hypothesis testing that has been conducted shows that partially compensation (X1) has a low, negative and significant effect on turnover intention (Y). Likewise, job satisfaction (X2) partially shows that there is a low, negative and significant influence on the turnover intention (Y) of PT Cipta Nugraha Contrindo office employees.
\end{abstract}

\section{Keyword : Compensation, Job Satisfaction, Turnover Intention}

\section{Latar Belakang}

Kebanyakan perusahaan dalam membangkitkan semangat kerja karyawan melalui kegiatan diantaranya : jalan jalan, kegiatan sosial, tunjangan tetap tiap bulan dan masihbanyak lagi. Berbeda dengan PT Cipta Nugraha Contrindo sebagai salah satu perusahaan besar yang bergerak di bidang jasa penyewaan kontraktor yang berada di daerah Jakarta Utara. Perusahaan ini sudah sudah berdiri sejak tahun 1994. PT Cipta Nugraha Contrindo sudah banyak berhasil 
menyelesaikan banyak proyek besar seperti PT Sari Roti, PT Indomarco, Indofood, Adira, $h i$ delight dan perusahaan lainya. Akan tetapi kesuksessan perusahaan ini tidak sesukses karyawannya dalam bekerja. Hal ini nampak bahwa perusahaan tidak membangkitkan semangat kerja karyawannya dan hanya memperhatikan keuntungan perusahaan saja, yang pada akhirnya membuat karyawan menjadi bermalas - malasan dalam bekerja karena tidak dihargainya kerja keras karyawan dalam bekerja, sehingga muncul fenomena keinginan karyawan yang keluar.

Kenaikan turnover intention pada karyawan PT Cipta Nugraha Contrindo periode 20152020 karyawan yang berkeinginan keluar dengan beralasan mencari pekerjaan yang lebih baik karena pendapatan / gaji yang diterima tidak sesuai dengan kebutuhannya. Dan karyawan yang telah berpendidikan sarjana menganggap gaji yang ia terima tidak sesuai dengan pendidikan terakhirnya serta status pekerja disana selalu kontrak dan tidak ada kelanjutan menjadi karyawan tetap dan memilih pekerjaan dengan penawaran yang lebih menarik. Ditambah lagi kenaikan turnover intention pada tahun 2020 menjadi paling tinggi dikarenakannya adanya pengurangan karyawan disebabkan oleh covid-19, karena pelanggan PT Cipta Nugraha Contrindo berkurang mengakibatkan pemasukan berkurang, sehingga keluar masuk karyawan bisa dicermati dalam tabel dibawah ini :

Tabel : Daftar Perputaran Karyawan PT Cipta Nugraha Contrindo Jakarta, Periode 2015- 2020

\begin{tabular}{|c|c|c|c|c|c|}
\hline Tahun & $\begin{array}{c}\text { Jumlah } \\
\text { Karyawan }\end{array}$ & $\begin{array}{c}\text { Karyawan } \\
\text { Masuk }\end{array}$ & $\begin{array}{c}\text { Persentase } \\
\text { Karyawan } \\
\text { Masuk }\end{array}$ & $\begin{array}{c}\text { Karyawan } \\
\text { Keluar }\end{array}$ & $\begin{array}{c}\text { Persentase } \\
\text { Karyawan } \\
\text { Keluar }\end{array}$ \\
\hline 2015 & 127 & 2 & $1,5 \%$ & 7 & $5,5 \%$ \\
\hline 2016 & 122 & 0 & 0 & 13 & $10,6 \%$ \\
\hline 2017 & 109 & 5 & $4,5 \%$ & 10 & $9,1 \%$ \\
\hline 2018 & 104 & 7 & $6,7 \%$ & 16 & $15,3 \%$ \\
\hline 2019 & 95 & 3 & $3,1 \%$ & 16 & $16,8 \%$ \\
\hline 2020 & 82 & 4 & $4,8 \%$ & 22 & $26,8 \%$ \\
\hline
\end{tabular}

Sumber : PT Cipta Nugraha Cotrindo ( data diolah ).

Permasalahan kerja yang di rasakan oleh karyawan PT Cipta Nugraha Contrindo adalah keinginan untuk keluar sangat tinggi, walaupun mereka telah di kontrak dan belum habis masa kontrak yang ada dikarenakan ada hal - hal berikut ini :

1. Budaya organisasi: Proses rekruitmen karyawan tetap yang terjadi karena adanya orang dalam atau orang yang dikenal sama atasan lebih cepat masuk dibandingkan karyawan yang murni proses kerjanya.

2. Kepuasan kerja : Job deskription yang ada bertambah karena ada karyawan yang keluar akibat naiknya turnover intention.

3. Gaya kepemimpinan: walaupun tidak pernah membedakan karyawan yang satu dengan yang lainnya, namun kurang memperhatikan keluhan - keluhan karyawan.

4. Kompensasi :Kompensasi yang tidak sesuai ( dirasakan kecil) dan tidak ada standar yang baku dalam pemberian gaji

5. Pengembangan karir : Tidak pernah memberikan pelatihan dan seminar kerja sesuai job desk masing- masing agar karyawan bisa menunjang pekerjaannya.

Menurut Harninda dalam (Sopiah \& Sangadji, 2018:208) turnover intention adalah 
keinginan berpindahnya karyawan dari perusahaan ke perusahaan lain untuk mencapai kepuasan karyawan dalam bekerja. Adapun faktor penyebabnya menurut Mobley dalam (Mujiati \& Dewi, 2016:1) adanya faktor ekternal dan faktor internal yang menyebabkan keinginan karyawan berpindah kerja. Faktor eksternal meliputi aspek lingkungan dimana banyak tersedianya pekerjaan lain yang dapat menjadi faktor keinginan keluar dan aspek internal / individu meliputi: usia masih muda, jenis kelamin, tingkat pendidikan, dan masa kontrak kerja lebih singkat, besar kemungkinan untuk mendorong keluar. Apalagi di perusahaan / dilapangan banyak faktor yang meliputi budaya organisasi, gaya kepemimpinan, kompensasi, kepuasan kerja, pengembangan karir, lingkungan kerja, beban kerja menjadi pemicunya.

Sedangkan dalam penelitian sebelumnya yang dilakukan oleh Ainan \& Listyorini, 2017 dengan judul "Pengaruh Kepuasan Kerja, Kompensasi, dan Iklim Organisasi Terhadap Turnover Intention Karyawan PT Putra Patra Utama Semarang". Hasil penelitian ini dapat disimpulkan bahwa kepuasan kerja, kompensasi, dan iklim organisasi berpengaruh negatif dan signfikan terhadap turnover intention pada karyawan PT Putra Patra Utama. Hal ini diperkuat dengan penelitian yang dilakukan oleh Rahmat \& dkk, 2019 dengan judul "Pengaruh Kompensasi dan Kepuasan Kerja Terhadap Turnovert Intention Pada Pizza Hut Palu. Dimana hasilnya juga menunjukkan bahwa kompensasi dan kepuasan kerja berpengaruh negatif dan signifikan terhadap turnovert intention.

Dari uraian singkat dari latar belakang diatas, maka tertarik untuk melakukan penelitian dengan tujuan sebagai berikut :

1. Untuk mengetahui seberapa besar pengaruh kompensasi terhadap turnover intentionpada PT Cipta Nugraha Contrindo.

2. Untuk mengetahui seberapa besar pengaruh kepuasan kerja terhadap turnoverintention pada PT Cipta Nugraha Contrindo.

\section{Tinjauan Pustaka \\ PengertianTurnover Intention}

Turnover Intention adalah keinginan seorang untuk keluar meninggalkan pekerjaan setelah karyawan diterima dalam suatu perusahaan. Hal ini tentu banyak pertimbangan yang dipikirkan oleh karyawan untuk pindah pekerjaan ke pekerjaan lainnya. Seperti Sopiah \& Sangadji ( 2018:208 ) mengatakan juga bahwa Turnovert Intention pada intinya yaitu berhendak pindahnya seorang karyawan dari satu pekerjaan ke pekerjaan lain nya". Kalau hal ini terjadi, tentunya perusahaan harus bertindak segera karena akan mengganggu kelangsungan perusahaan di masa mendatang.

Menurut Robbins dalam Kartono, (2017:44) Turnovert Intention mendefinisikan sebagai bentuk keinginan berhenti karyawan yang bersifat permanen dari perusahaan baik yang dilakukan oleh pegawai sendiri (secara sukarela) maupun yang dilakukan oleh perusahaan yang dapat mengakibatkan tingginya biaya pengelolaan sumber daya manusia. Dengan demikian pengertian para ahli diatas turnovert intention adalah merupakan keinginan keluar atau berhenti dan menjadi karyawan perusahaan lain agar mendapatkan pekerjaan yang lebih baik lagi. Biasanya keputusan keinginan keluar menjadi keputusan yang paling akhir setelah megukur yang telah ia dapatkan bekerja selama ini. Karena banyak faktor yang mempengaruhinya. Menurut Mobley dalam (Mujiati \& Dewi, 2016:9) dalam menentukan pergantian karyawan dapat dibedakan menjadi dua, yaitu :

1. Faktor organisasional seperti jabatan, penggajian sering memicu kecenderungan karyawan untuk turnover intention 
2. Faktor individual seperti usia yang lebih muda lebih sering terjadinya turnover intention, karena karyawan yang lebih muda usinya lebih besar kesempatannya untuk pindah, dan Masa kerja sering juga terjadi pergantian karyawan, apalagi karyawan yang masa kerjanya lebih rendah.

Sedangkan indikator dalam turnover intention menurut Harnoto dalam (Sopiah \& Sangadji, 2018:209) adalah pertama, tingkat absensi yang meningkat. Kedua, mulai jenuh dalam bekerja dengan ditandai malas bekerja. Ketiga. peningkatan pelanggaran tata tertib yang dilakukan oleh karyawan. Keempat, meningkatnya protes keatasan terhadap kebijakan perusahaan kepada pimpinan. Kelima, perilaku yang berbeda dari biasanya seperti dulu sering bertanggung jawab sekarang sangat kurang bertanggung jawab.

\section{Pengertian Kompensasi}

Kompensasi menjadi hal yang paling diperhatikan dan mendasar yang dinilai karyawan terhadap perusahaannya. Karena kompensasi merupakan balas jasa perusahaan dan penghargaan terhadap karyawan yang telah memberikan kemampuannya dalam bekerja untuk perusahaan. Kompensasi yang diberikan oleh perusahaan berupa gaji, tunjangan, bonus dan lain - lain untuk mencapai tujuan. Hal ini sesuai pengertian kompensasi menurut Bangun (2020:255) yaitu kompensasi adalah sesuatu yang karyawan terima atas tenaga dan pengetahuan yang ia berikan ke perusahaan untuk mencapai tujuan.

Sedangkan pengertian kompensasi menurut Kasmir (2016:255) adalah sebagai bentuk penghargaan atas jasa karyawan, dimana memiliki indikator - indikator kompensasi menurut Edy Sutrisno dalam ( Rahmawati \& Dkk, 2020:14 ) yaitu : pertama, gaji dimana merupakan kompensasi yang diberikan kepada karyawan secara rutin ( per bulan ). Kedua, Tunjangan adalah yang diberikan perusahaan kepada para karyawannya, karena karyawan tersebut dianggap telah ikut berpartisipasi dalam mencapai tujuan perusahaan, baik tunjangan finansial, maupun non finansial. Ketiga, Insentif adalah sesuatu yang di berikan kepada karyawan tertentu karena keberhasilan dalam prestasinya.

\section{Pengertian Kepuasan Kerja}

Kebutuhan karyawan sangat beragam baik jenis maupun tingkatannya, maka karyawan sebagai manusia ingin memenuhi kebutuhannya setiap hari agar mendapatkan kepuasan kerja. Menurut Buhler (Zainal Dkk, 2018:623) mengemukakan bahwa "Kepuasan kerja adalah kesuksesan seseorang dalam menyelesaikan pekerjaan sesuai job desk yang telah disepakati sebelumnya agar mencapai hasil kerja yang diinginkan". Sedangkan Kepuasan kerja menurut Busch dalam (Sutrisno, 2017:76) "Kepuasan kerja adalah perasaan senang atau tidak senang yang ditunjukkan terhadap pekerjaannya. Sehingga seseorang yang merasa puas terhadap pekerjaanya maka ia akan tetap bertahan lama diperusahaan dan dapat menurunkan angka keluar masuk karyawan.

Berdasarkan pengertian menurut para ahli diatas kepuasan kerja adalah perasaan senang atau tidak senang terhadap pekerjaan yang di jalani berupa pengalaman menyenangkan dan tidak menyenangkan. Sedangkan indikator kepuasan kerja menurut Yuwono dalam (Badriyah, 2015:241) antara lain gaji, promosi, kepemimpinan, tunjangan dan rekan kerja. Hal ini sering menyebabkan muncul turnover intention di perusahaan.

\section{Kerangka Pemikiran \\ Pengaruh Kompensasi Terhadap Turnover Intention}


Perusahaan memberikan kompensasi disesuaikan dengan kemampuan karyawan dan pengalaman berorganisasi selama ini. Perusahaan setiap saat berusaha memberikan yang terbaik untuk karyawan yang telah bertanggung jawab atas pekerjaannya. Kesesuaian pemberian kompensasi akan berdampak positif bagi dua belah pihak yaitu karyawan dan perusahaan, untuk karyawan bisa memenuhi kebutuhaannya setiap hari dan bagi perusahaan menjadi maju dan tercapai tujuannya.

Pengaruh kompensasi menurut Kasmir diatas adalah sebagai bentuk penghargaan atas jasa karyawan, dimana kompensasi dibayarkan oleh perusahaan secara wajar dan benar maka tidak ada niat karyawan yang ingin keluar dan karyawan tetap akan terus bertahan. Kesesuaian kompensasi yang diberikan perusahaan dengan tanggung jawab pekerjaan karyawan masing - masing tentunya akan menurunkan timbulnya tunover intention. Perhatikan rendahnya turnovert intention akan memberikan dampak yang positif untuk kemajuannya sumber daya manusia dan perusahaan itu sendiri. Begitupun sebaliknya jika perusahaan tidak memberikan kompensasi yang sesuai dengan apa yang telah karyawan lakukan maka ada kecenderungan timbulnya masalah bagi peningkatan turnover intention.

Hal ini didukung dengan penelitian terdahulu yang dilakukan oleh (Ainan \& Listyorini, 2017) yang berjudul "Pengaruh Kepuasan Kerja, Kompensasi, Dan Iklim Organisasi Terhadap Tunover Intention Karyawan PT Putra Patra Utama Semarang". Hasil dari penelitian ini dapat menyimpulkan bahwa kompensasi berpengaruh negatif dan signifikan terhadap turnover intention karyawan PT. Putra Patra Utama Semarang. Berdasarkan uraian pengaruh kompensasi dengan turnover intention dengan penelitian terdahulu, maka dapat dirumuskan hipotesis sebagai berikut: H1 : Kompensasi berpengaruh terhadap turnover intention.

\section{Pengaruh Kepuasaan Kerja Terhadap Turnover Intention}

Kepuasan kerja terjadi seiring meningkatnya apresisasi kerja terhadap karyawan. Meningkatnya apresiasi kerja bagi karyawan akan membangun semangat kerja karyawan untuk memberikan yang terbaik bagi perusahaan. Misalkan job deskription yang di berikan oleh atasan sesuai dengan pekerjaan atau tanggung jawab yang telah di dapat oleh karyawan masing -masing telah dilaksanakan. Karyawan akan merasa puas dan di hargai jika atasan memberikan tanggung jawab pekerjaan secara merata dan adil. Selain itu atasan harus dapat memberikan apresiasi untuk karyawannya sendiri, hingga menjadi puas akan pekerjaannya dan bagi atasan juga senang dapat tercapainya tujuan yang diinginkan perusahaan.

Adapun apresiasi kerja bagi karyawan harus bisa diberikan atasan secara kontinyu, karena yang di berikan oleh atasan akan menurunkan keinginan karyawan untuk keluar / pindah, sehingga timbul turnover intention bisa dikendalikan. Begitupun sebaliknya seorang karyawan yang merasa perasaannya kurang puas terhadap pekerjaannya akan menimbulkan turnover intention yang tinggi. Hal ini diperkuat secara teoritis dari pendapat ahli seperti kepuasan kerja menurut Busch dalam (Sutrisno, 2017:76) adalah "perasaan senang atau tidak senang yang ditunjukkan terhadap pekerjaannya". Seseorang yang merasa puas terhadap pekerjaanya maka ia akan tetap bertahan dan lama di perusahaan dan dapat menurunkan angka keluar masuk karyawan". Hal ini didukung dengan penelitian sebelumnya yang dilakukan oleh (Bibowo \& Masdupi, 2015) yang berjudul "Pengaruh Kepuasan Kerja, Kompensasi, dan Pengembangan Karir Terhadap Turnovert Intention Karyawan Bank Syariah Mandiri Cabang Padang" hasil dari penelitian ini dapat disimpulkan bahwa kepuasan kerja berpengaruh signifikan dan negatif terhadap turnover intention karyawan BSM cabang Padang. Berdasarkan uraian dan hasil penelitian tersebut diatas, maka dapat dirumuskan hipotesis sebagai berikut: 
$\mathrm{H} 2$ : Kepuasaan kerja berpengaruh terhadap turnover intention

Melihat keterkaitan antar variable kompensasi ( X1 ), dan kepuasan kerja ( X2 ), terhadap turnover intention ( $\mathrm{Y}$ ), dapat dibuat dengan model kerangka pemikiran sebagai berikut :

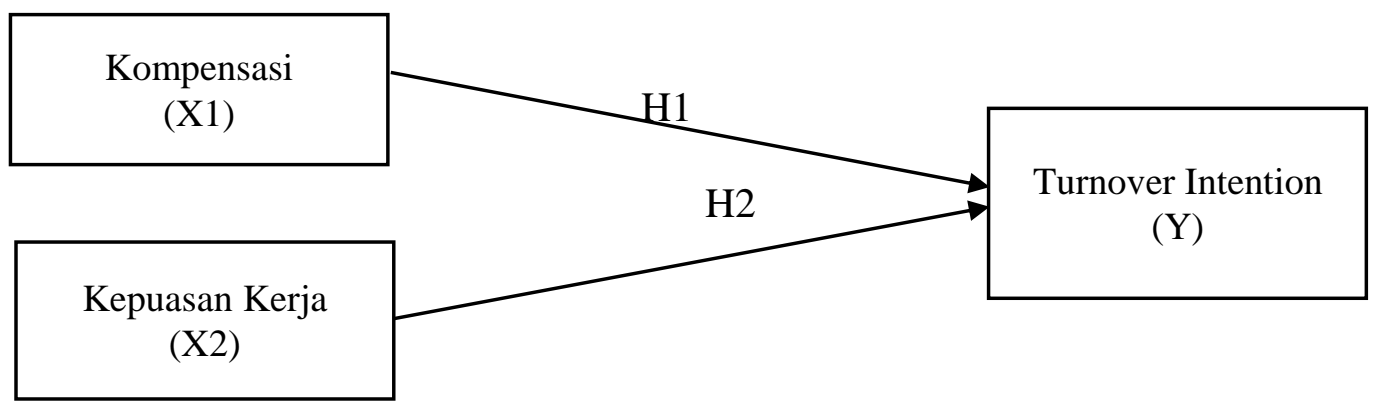

Gambar : Kerangka pemikiran

\section{Metode Penelitian}

Pengumpulan data menggunakan data primer yang diperoleh dari penyebaran kuisoner dengan menggunakan skala likert, yang berisi pernyataan yang sebelumnya dilakukan uji validitas dan realibilitas. Kuisoner disebarkan pada populasi seluruh karyawan office PT Cipta Nugraha Contrindo yang berjumlah 64 karyawan, menggunakan sampling jenuh. Adapun teknik analisa data menggunakan teknik analisis regresi sederhana, yang sebelumnya terlebih dahulu dilakukan uji asumsi klasik sebagai persyaratan dalam sebuah analisis agar datanya dapat dianalisis secara lebih meyakinkan.

Sedangkan variabel dan pengukuran telah dilakukan uji validitas dan realibilitas, berdasarkan definisi operasional, sebagai berikut :

- Turnover intention ( Y ) adalah keinginan keluar atau berhenti karyawan PT Cipta Nugraha Contrindo di perusahaan agar mendapatkan pekerjaan yang lebih baik lagi, dengan indikator absensi yang meningkat, mulai jenuh dalam bekerja, peningkatan pelanggaran tata tertib kerja.

- Kompensasi ( X1 ) merupakan balas jasa atau timbal balik yang diberikan perusahaan kepada karyawan PT Cipta Nugraha Contrindo berupa gaji, tunjangan, insentif

- Kepuasan kerja ( X2 ) adalah perasaann senang atau tidak senang terhadap pekerjaan pada karyawan PT Cipta Nugraha Contrindo yang mereka jalani berupa pengalaman dari indikator Tugas Pekerjaan, Tunjangan, Kepemimpinan, dan Rekan Kerja

\section{Hasil Analisis dan Pembahasan}

\section{Pengaruh Kompensasi ( $\left.\mathbf{X}_{1}\right)$ Terhadap Turnover Intention (Y)}

Penggunan analisis regresi sederhana dari variabel kompensasi (X1) terhadap turnover intention (Y), melalui program SPSS 26 diperoleh data sebagai berikut : 
KINERJA Jurnal Ekonomi dan Bisnis Vol. 4 No. 1 - Desember 2021

\begin{tabular}{|c|c|c|c|c|}
\hline \multirow[b]{3}{*}{ Model } & & \multicolumn{3}{|c|}{ Coefficients $^{a}$} \\
\hline & & \multicolumn{2}{|c|}{ Unstandardized Coefficients } & \multirow{2}{*}{$\begin{array}{c}\text { Standardized } \\
\text { Coefficients } \\
\text { Beta }\end{array}$} \\
\hline & & $\mathrm{B}$ & Std. Error & \\
\hline \multirow[t]{2}{*}{1} & (Constant) & 61,912 & 5,569 & \\
\hline & Kompensasi &,- 428 & ,135 &,- 373 \\
\hline
\end{tabular}

a. Dependent Variable: Turnover Intention

Berdasarkan koefisien regresi diatas diperoleh persamaan regresi sederhana, adalah sebagai berikut : $\mathrm{Y}=61,912-0,428 \mathrm{X}_{1}$, maka dapat diartikan sebagai berikut :

a. Konstanta $=61,912$ Jika variabel kompensasi (X1) dianggap sama dengan nol atau tidak berubah, maka variabel turnover intention $(\mathrm{Y})$ sebesar 61,912.

b. Koefisien $\mathrm{X}_{1}=-0,428$, Jika variabel kompensasi ditingkatkan satu kali, maka turnover intention akan menurun sebesar 0,428 satu satuan

Adapun perhitungan dari koefisien korelasi sederhana (r) dari variabel Kompensasi ( X1 ) Terhadap Turnover Intention ( Y ) adalah sebagai berikut :

\begin{tabular}{|c|c|c|c|}
\hline \multicolumn{4}{|c|}{ Correlations } \\
\hline & & Kompensasi & $\begin{array}{l}\text { Turnover } \\
\text { Intention }\end{array}$ \\
\hline \multirow[t]{3}{*}{ Kompensasi } & Pearson Correlation & 1 & $-.373^{\star \pi}$ \\
\hline & Sig. (2-tailed) & & .002 \\
\hline & $N$ & 64 & 64 \\
\hline \multirow[t]{3}{*}{ Turnover Intention } & Pearson Correlation & $-.373^{\pi *}$ & 1 \\
\hline & Sig. (2-tailed) &, 002 & \\
\hline & $\mathbf{N}$ & 64 & 64 \\
\hline
\end{tabular}

Hasil diatas dapat diketahui bahwa nilai pearson correlation (r) dari Kompensasi (X1) terhadap Turnover Intention ( $Y$ ) sebesar - 0,373 hal ini menunjukkan bahwa adanya keeratan korelasi yang rendah. Adapun koefisien determinasi diperoleh dengan $r 2=(0,373)^{2}=0,139$. Dimana nilai $r^{2}$ sebesar 0,139 atau 13,9\% yang artinya kompensasi (X1) memberikan sumbangan terhadap Turnover Intention (Y) karyawan sebesar 13,9 \% maka masih banyak faktor lain yang mempengaruhi Turnover Intention sebesar 86,1\%

Untuk uji hipotesis menggunakan uji t yaitu menguji signifikan secara parsial dari variabel kompensasi ( X1 ) terhadap variabel Turnover Intention ( Y ). Adapun hasil uji t dapat dilihat sebagai berikut :

\section{Hasil Uji t}

\begin{tabular}{|c|c|c|c|c|c|c|}
\hline \multirow{2}{*}{\multicolumn{2}{|c|}{ Model }} & \multicolumn{2}{|c|}{ Unstandardized Coefficients } & \multirow{2}{*}{$\begin{array}{c}\text { Standardized } \\
\text { Coefficients } \\
\text { Beta }\end{array}$} & \multirow[b]{2}{*}{$\mathrm{t}$} & \multirow[b]{2}{*}{ Sig } \\
\hline & & $\mathrm{B}$ & Std. Error & & & \\
\hline 1 & (Constant) & 61,912 & 5,569 & & 11,118 &, 000 \\
\hline
\end{tabular}


KINERJA Jurnal Ekonomi dan Bisnis Vol. 4 No. 1 - Desember 2021

\begin{tabular}{ll|l} 
Kompensasi &,- 428 &, 135
\end{tabular} $-, 373 \quad-3,162$ , 002

Berdasarkan perolehan $\mathrm{t}$ hitung sebesar $-3,162$ lebih besar dari $\mathrm{t}$ table ( $\mathrm{t}$ hitung 3,162 $>\mathrm{t}$ tabel 1,671) yang berarti bahwa variable kompensasi ( X1 ) berpengaruh terhadap Turnover Intention ( Y ) karyawan. Adapun taraf signifikan kompensasi (X1) terhadap Turnover Intention ( Y ) karyawan sebesar 0,002 dimana tingkat signifikan $(0,002<0,05)$, maka dapat disimpulkan bahwa Ho ditolak Ha diterima yang artinya kompensasi (X1) dapat berpengaruh negatif dan signifikan terhadap terhadap turnover intention (Y ) karyawan pada PT Cipta Nugraha Contrindo telah diterima dan terbukti

Melhat hasil penelitian diatas ternyata pengaruh kompensasi ( X1 ) terhadap turnover intension yang rendah, apalagi kontribusinya hanya sebesar 13, $9 \%$ yang menunjukkan banyak faktor - faktor lain yang ikut mempengaruhinya. Sedangkan permasalahan dalam kompensasi pada PT Cipta Nugraha Contrindo yaitu kurang besarnya kompensasi yang diberikan perusahaan, seperti gaji yang tidak sesuai dengan ketetapan peraturan pemerintah dan tidak sesuai dengan masa kerja karyawan sebenarnya merupakan hal yang biasa. Dimana karyawan diberikan kompensasi dengan adil sesuai ketetapan peraturan pemerintah yang ada, maka karyawan dan perusahaan akan bisa mencapai tujuan bersama.

Adapun hipotesis penelitian ini diterima, yang berarti sesuai dengan teori yang diacu dalam landasan teori menurut Kartono ( 2017:44) turnover intention ialah sebagai bentuk keinginan berhenti dari karyawan yang bersifat permanent dari perusahaan baik yang dilakukan oleh pegawai sendiri ( secara sukarela ) maupun yang dilakukan oleh perusahaan yang dapat mengakibatkan tingginya turnover intention. Namun pengaruh pada perusahaan PT Cipta Nugraha Contrindo adalah rendah, artinya belum terlalu merisaukan bagi perusahaan namun perlu diwaspadai kecenderungan kompensasi bermasalah atau menurun akan meningkatkan turnover intention.

Sedangkan penelitian terdahulu yang dilakukan oleh (Rahmat \& dkk, 2019) dengan judul "Pengaruh Kompensasi dan Kepuasan Kerja Terhadap Turnover Intention PadaPizza Hut Pallu". Dimana hasil penelitian ini dapat disimpulkan bahwa kompensasi dan kepuasan kerja berpengaruh negatif terhadap turnover intention. Kalau melihat dua variabel tersebut dihubungkan dengan variabel turnover intention pada perusahaan PT Cipta Nugraha Contrindo dengan melihat fenomena yang ada, sangat dirasakan oleh karyawan yang mana keinginan keluar mencari pekerjaan yang lebih baik. Maka banyak terbukti dalam hasil penelitian yang lain juga mempunyai indikasi yang sama, terhadap turnover intention, baik secara partial maupun simultan.

\section{Pengaruh Kepuasan Kerja $\left(\mathbf{X}_{2}\right)$ Terhadap Turnover Intention (Y)}

Hasil regresi sederhana dari variabel kepuasan kerja (x2) terhadap turnover intention (Y), melalui program SPSS 26 diperoleh data sebagai berikut :

\begin{tabular}{|c|c|c|c|c|c|}
\hline \multirow[b]{4}{*}{ Model } & \multicolumn{4}{|c|}{ Coefficients $^{a}$} & \\
\hline & \multirow{2}{*}{\multicolumn{2}{|c|}{ Unstandardized Coefficients }} & Standardized & & \\
\hline & & & Coefficients & & \\
\hline & B & Std. Error & $\begin{array}{c}\text { Bet } \\
\text { a }\end{array}$ & $\mathrm{t}$ & $\mathrm{Sig}$ \\
\hline (Constant) & 64,990 & 6,638 & & 9,790 &, 000 \\
\hline
\end{tabular}


KINERJA Jurnal Ekonomi dan Bisnis Vol. 4 No. 1 - Desember 2021

\begin{tabular}{lll|l|l|l|l}
\hline 1 & Kepuasan Kerja &,- 550 &, 177 &,- 368 & $-3,113$ &, 003 \\
\hline
\end{tabular}

a. Dependent Variable: Turnover Intention

Berdasarkan hasil koefisien regresi diatas diperoleh persamaan regresi sederhana, adalah sebagai berikut : $\mathrm{Y}=64,990-0,550 \mathrm{X}_{2}$, maka dapat diartikan sebagai berikut :

a. Konstanta $=64,990$ Jika variabel kepuasan kerja (X2) dianggap sama dengan nol atau tidak berubah, maka variabel turnover intention (Y) sebesar 64,990.

b. Koefisien $\mathrm{X} 2=-0,550$, Jika variabel kompensasi ditingkatkan satu kali, maka turnover intention akan menurun sebesar 0,550 satu satuan

Adapun perhitungan dari koefisien korelasi sederhana (r) variabel kepuasan kerja ( X2 ) Terhadap Turnover Intention ( $\mathrm{Y}$ ) adalah sebagai berikut :

\section{Correlations}

\begin{tabular}{llc|c} 
& \multicolumn{2}{l}{ Kepuasan Kerja } & $\begin{array}{l}\text { Turnover } \\
\text { Intention }\end{array}$ \\
\hline \multirow{2}{*}{ Kepuasan Kerja } & Pearson Correlation & 1 &,$- 368^{* *}$ \\
\cline { 2 - 4 } & Sig. (2-tailed) & &, 003 \\
\cline { 2 - 4 } & $\mathrm{N}$ & 64 & 64 \\
\hline \multirow{3}{*}{ Turnover Intention } & Pearson Correlation &,$- 368^{* *}$ & 1 \\
\cline { 2 - 4 } & Sig. (2-tailed) &, 003 & \\
\cline { 2 - 4 } & $\mathrm{N}$ & 64 & 64 \\
\hline
\end{tabular}

${ }^{* *}$. Correlation is significant at the 0.01 level (2-tailed).

Hasil diatas dapat diketahui bahwa nilai pearson correlation (r) dari variabel kepuasan kerja (X2) terhadap Turnover Intention (Y) sebesar $-0,368$ hal ini menunjukkan bahwa adanya keeratan korelasi yang rendah. Adapun perhitungan koefisien determinasi diperoleh dengan $r^{2}=(0,368)^{2}$ $=0,135$. Dimana nilai $\mathrm{r}^{2}$ sebesar 0,135 atau $13,5 \%$ yang artinya kepuasan kerja (X2) memberikan sumbangan terhadap Turnover Intention (Y) karyawan sebesar 13,5\% maka masih banyak faktor lain yang mempengaruhi Turnover Intention sebesar $86,5 \%$.

Untuk uji hipotesis menggunakan uji t yaitu menguji signifikan secara parsial dari variabel kepuasan kerja ( X2 ) terhadap variabel Turnover Intention ( Y ). Adapun hasil uji t dapat dilihat sebagai berikut :

\begin{tabular}{|c|c|c|c|c|c|c|}
\hline \multicolumn{7}{|c|}{ Hasil uji t } \\
\hline \multirow{2}{*}{\multicolumn{4}{|c|}{ Unstandardized Coefficients }} & & & \\
\hline & & & & Coefficients & & \\
\hline & & B & Std. Error & Beta & & Sig. \\
\hline \multirow[t]{2}{*}{1} & (Constant) & 64,990 & 6,638 & & 9,790 & ,000 \\
\hline & Kepuasan Kerja &,- 550 & 177 &,- 368 & $-3,113$ & ,003 \\
\hline
\end{tabular}

a. Dependent Variable: Turnover Intention 
Berdasarkan perolehan $\mathrm{t}$ hitung sebesar -3,113 lebih besar dari t table ( $\mathrm{t}$ hitung 3,113 > $\mathrm{t}$ tabel 1,671) yang berarti bahwa variable kepuasan kerja ( $\mathrm{X} 2$ ) berpengaruh terhadap turnover Intention ( $\mathrm{Y}$ ) karyawan. Adapun taraf signifikan kepuasan kerja (X2) terhadap turnover Intention ( $\mathrm{Y}$ ) karyawan sebesar 0,003 dimana tingkat signifikan $(0,003<0,05)$, maka dapat disimpulkan bahwa Ho ditolak Ha diterima yang artinya kepuasan kerja (X2) dapat berpengaruh negatif dan signifikan terhadap terhadap turnover intention ( $Y$ ) karyawan pada PT Cipta Nugraha Contrindo telah diterima dan terbukti.

Berdasakan variabel kepuasan kerja (X2) berpengaruh negatif dan signifikan terhadap variabel turnover intention, namun pada PT Cipta Nugraha Contrindo mempunyai pengaruh yang rendah dengan kontribusi sebesar sebesar 0,135 atau 13,5\% yang artinya kepuasan kerja (X2) memberikan sumbangan terhadap Turnover Intention (Y) karyawan sebesar 13,5\% maka masih banyak faktor lain yang mempengaruhi Turnover Intention sebesar 86,5\%. Sehingga fenomena keluar masuknya karyawan di perusahaan tersebut masih wajar, walaupun perlu diwaspadai karena ternyata masih banyak faktor - faktor lain yang mempengaruhi turnover intention.

Permasalahan dalam kepuasan kerja pada PT Cipta Nugraha Contrindo yaitu kurangnya kepuasan kerja terhadap kepemimpinan yang tidak adil dalam memberikan job desk terhadap karyawannya, memilah dan memilih karyawan menjadi karyawan tetap yang harus dekat dengannya. Kecemburuan karyawan tersebut terhadap atasan yang tidak bersikap adil dan membeda-bedakan karyawan, menyebabkan ketidakpuasan karyawan menjadi tertekan dalam menjalankan tugasnya dalam bekerja. Sehingga wajar muncul keinginan karyawan untuk keluar.

Adapun hasil hipotesis penelitian ini diterima, maka berarti menurut Keith Davis dalam (Mangkunegara, 2020:117) "Kepuasan kerja adalah perasaan senang ataupun tidak senang yang menggambarkan pekerjaannya dan dirinya terhadap job description yang diberikan oleh pimpinan. Dimana hal ini bisa saja memicu kenderungan karyawan ingin keluar mencari pekerjaan yang lebih baik, Hal ini didukung dengan penelitian terdahulu yang dilakukan oleh (Bibowo \& Masdupi, 2015) yang berjudul "Pengaruh Kepuasan Kerja, Kompensasi, dan Pengembangan Karir Terhadap Turnovert Intention Karyawan Bank Syariah Mandiri Cabang Padang", dimana hasil dari penelitian ini dapat disimpulkan bahwa kepuasan kerja berpengaruh signifikan dan negatif terhadap turnover intention karyawan BSM cabang Padang.

\section{Penutup}

Berdasarkan hasil penelitian dan pembahasan yang telah dilakukan, dengan pengujian hipotesis menggunakan uji t dapat diperoleh simpulan :

1. Variabel Kompensasi ( X1 ) secara parsial memiliki pengaruh yang rendah dan pengaruhnya yang negatif dan signifikan terhadap turn over intention $(\mathrm{Y})$

2. Variabel Kepuasan kerja (X2) secara parsial memiliki pengaruh yang rendah dan pengaruhnya yang negatif dan signifikan terhadap turnover intention $(\mathrm{Y})$.

\section{Saran}

Hasil penelitian pengaruh kompensasi (X1) dan kepuasan kerja ( X2 ) terhadap turnover intention (Y), maka penulis memberikan saran, sebagai berikut:

1. Dari hasil score penilaian responden, ada beberapa quisoner yang mendapat score rendah seperti penggajian yang tidak sesuai, kurang menaati peraturan ( penggunaan pakaian ) dan pekerjaan yang diberikan tidak menarik ( tidak sesuai job desk ), maka perusahaan dapat menindaklanjuti atau memperbaikinya

2. Berdasarkan penelitian diatas dengan analisa regresi sederhana terlalu sederhana, karena 
memiliki pengaruh dan kontribusinya rendah, baik dari variabel kompensasi (X1) dan kepuasan kerja ( X2 ) terhadap turnover intention (Y), nanti dikembangkan dengan variabel lainnya dengan menggunakan analisa regresi moderasi ataupun bisa menggunakan analisa jalur.

\section{Referensi}

Ainan, M., \& Listyorini, H. (2017). Pengaruh Kepuasan Kerja,Kompensasi Dan Iklim Organisasi Terhadap Turnover Intentions Karyawan Pt. Putra Patra Utama Semarang. Tunover Intention, $\quad 2, \quad 15-25 . \quad \mathrm{http}: / /$ stiepari.greenfrogts.co.id/jurnal/index.php/JVM/article/view/60/63

Ajabar. (2020). Sumber Daya Manusia (1st ed.). Deepulish.

Anshori, M., \& Iswati, S. (2017). Metodologi Penelitian Kuantitatif (1st ed.). Airlangga University Press.

Ansory, A. F., \& Indrasari, M. (2018). Manajemen Sumber Daya Manusia (1st ed.). Indomedia Pustaka.

Ardan, M., \& Jaelani, A. (2021). Manajemen Sumber Daya Manusia: Turnover Intention dapat mempengaruhi kualitas kinerja perusahaan (1st ed.). CV Pena Persada.

Arifin, N. (2019). Manajemen Sumber Daya Manusia Teori dan Kasus.

Badriyah, M. (2015). Manajemen Sumber Daya Manusia (1st ed.). CV Pustaka Setia. Bangun, W. (2020). Manajemen Sumber Daya Manusia (Tim Perti 1 (ed.)). PT Gelora

Aksara Pratama.

Bibowo, A., \& Masdupi, E. (2015). Pengaruh kepuasan kerja, kompensasi, dan pengembangan karir terhadap turnovert intention karyawan bank syariah mandiri cabang padang.

Turnover Intention, 3, 1-16. http://ejournal.unp.ac.id/index.php/jrmbp/issue/view/604

Hasibuan, M. S. . (2016). Manajemen Sumber Daya Manusia. PT Bumi Aksara. Kartono. (2017). Personality, Employee Engagement, Emotional, Intellegence, Job

Burnout Pedekatan Dalam Melihat Turnover Intention. Deepulish.

Kesumawati, N. dkk. (2017). Pengantar Statistika Penelitian (1st ed.). PT RajaGrafindoPersada.

Khaidir, M., \& Sugiati, T. (2016). Pengaruh Stres Kerja, Kompensasi Dan Kepuasan Kerja Terhadap Turnover Intention Studi Pada Karyawan Kontrak PT Gagah SatriaManunggal Banjarmasin. Jurnal Wawasan Manajemen, 4(3), 175-185. https://jwm.ulm.ac.id/id/index.php/jwm/article/view/93

Mangkunegara, A. A. A. P. (2020). Manajemen Sumber Daya Manusia Perusahaan (S. Sandiasih (ed.); 14th ed.). PT Remaja Rosdakarya.

Marjuni, S. (2015). Buku Ajar Manajemen Sumber Daya Manusia (S. Haerani (ed.); 1sted.). CV. Sah Media. 
KINERJA Jurnal Ekonomi dan Bisnis Vol. 4 No. 1 - Desember 2021

Mujiati, N. W., \& Dewi, A. A. S. K. (2016). Jurnal Ilmiah Forum Manajemen. 14.

Notoatmodjo, S. (2015). Pengembangan Sumber Daya Manusia (5th ed.). PT Rineka Cipta.

Novitasari, E. S. . (2020). Dasar - Dasar Ilmu Manajemen Pengantar Menguasai Ilmu Manajemen (1st ed.). Unicorn.

Paulus, E., \& Winoto Tj, H. (2015). Pengaruh Kompensasi dan Kepuasan Kerja Terhadap Turnover Intention Karyawan (Studi Kasus Pada PT Multi Abadi Sejahtera). Turnover Inte, $15, \quad 2$.

http://ejournal.ukrida.ac.id/ojs/index.php/IMB/article/view/1321/1461

Rahmat, \& dkk. (2019). Pengaruh Kompensasi Dan Kepuasan Kerja Terhadap TurnoverIntention Pada Pizza HUT Palu. Tunover Intention, 5(September), 311-319. https://jimutuntad.com/index.php/jimut/article/view/162

Rahmawati, I., \& Dkk. (2020). Faktor kompensasi, motivasi, dan disiplin kerja karyawan (studi pada dinas kesehatan kabupaten jombong). Universitas KH.A Wahab Hasbullah.

Rivai, Z. V., \& Dkk. (2018). Manajemen Sumber Daya Manusia untuk Perusahaan Dari Teori ke Praktik (8th ed.). PT RajaGrafindo Persada.

Saihudin. (2019). Manajemen Sumber Daya Manusia (Gianto (ed.); 1st ed.). Uwais Inspirasi Indonesia.

Sari, R. N. (2014). Pengaruh Kepuasan Kerja, Stres Kerja Dan Komitmen Organisasi Terhadap Turnover Intention. Tunover Intention. https://eprints.uny.ac.id/15137/1/SKRIPSI.pdf

Sopiah, \& Sangadji, E. M. (2018). Manajemen Sumber Daya Manusia Strategik (Dwi Prabantini (ed.); 1st ed.). CV Andi Offset.

Sudaryo, Y., \& dkk. (2019). Manajemen Sumber Daya Manusia, Kompensasi Tidak Langsung, Dan Lingkungan Kerja Fisik (T. Erang (ed.); 1st ed.). ANDI (Anggota IKAPI).

Sujarweni, wiratna. (2018). Metodologi Penelitian bisnis dan ekonomi (1st ed.). Pustaka baru press.

Sutrisno, E. (2017). Manajemen Sumber Daya Manusia. Kencana.

Sujarweni, (2018) Metodologi Penelitian bisnis dan ekonomi. 1st edn.Yogyakarta:Pustaka baru press.

Kasmir. 2016. Manajemen Sumber Daya Manusia (Teori dan Praktik). Depok: PTRajagrafindo Persada 